\title{
Petroleum Engineering English Vocabulary Course Design Based on Memetics
}

\author{
Jinlin Yu \\ College of Foreign Languages, Northeast Petroleum University, Daqing, 163318, China \\ Email: tzctzq@163.com
}

Keywords: Memetics; Vocabulary Memes; Petroleum Engineering English Vocabulary Teaching

\begin{abstract}
Because petroleum engineering English vocabulary is too professional and is used at relatively low frequency, it's very hard for students to remember. Therefore, to help students recite and grasp petroleum engineering English vocabulary rapidly and solidly, the course design based on memetics is planned and carried out through a teaching experiment. Experiment shows that the vocabulary proficiency of students guided by memetics-oriented petroleum engineering English vocabulary teaching method is improved much more than those taught by traditional method. Memetics-oriented petroleum engineering English vocabulary teaching method can not only make a positive influence on students' vocabulary learning, but also is relatively more effective than the traditional petroleum engineering English vocabulary teaching way.
\end{abstract}

\section{Introduction}

With the increasing growth of global technological and economic integration, as well as the further development of reform in petroleum industry, the scale of overseas contracting and cooperative oilfields is enlarging continually, and the internationalization of the petroleum enterprise is growing rapidly. Hence, petro-tech personnel who knows both specialty and English well is needed, to take up international technical exchanges and technical cooperation in the field of petroleum exploration. However, in sharp contrast to such a social demand, the petroleum engineering English abilities of university students are still lowering. One of the most important reasons for the poorer English ability of the students is that there is a very large amount of petroleum vocabulary in the petroleum engineering English. The features of the petroleum vocabulary are most words are very long and far different from the common words used daily. Students can't remember these words easily. On the other hand, the traditional way of teaching petroleum vocabulary is just teaching students the textbook-based discrete vocabulary, but not in systematic way and without any teaching vocabulary strategies. Therefore, English teachers in the petroleum university are facing a challenge, which is how to teach students petroleum vocabulary more efficiently and effectively.

Memetics, based on the theory of evolution by Darwin, is a new theory to explain cultural evolution. According memetics, meme is just a type of "unit of cultural transmission". All the things learning from others by imitation are memes. So language is a kind of meme. Linguistic memetics mainly study language itself and related phenomena from the perspective of memetics. Meme does benefits to the development of language on one hand, but is replicated and transmitted depending on language on the other hand.

Based on the theory of memetics, a course design on petroleum engineering English vocabulary teaching through a teaching experiment is carried out. To ensure the effectiveness of the experiment, two parallel classes in Petroleum Engineering College of Northeast Petroleum University are chosen to be the experimental subjects. Pre-test and post-test are given before and at the end of the research respectively. All the collected data are dealt with software SPSS19.0. 


\section{Course Design and Implementation of Memetics-oriented Petroleum Engineering English Vocabulary Teaching}

Subjects of this research are composed of 60 students and one college English teacher. All these students are petroleum-majored junior students coming from Class One and Class Two in College of Petroleum Engineering of Northeast Petroleum University. According to the arrangement of the university, the two parallel petroleum-majored classes are taught by the same English teacher, but at different time. Class One with 30 students was assigned as experimental class and taught in the memetic way, whereas Class Two with another 30 students as control class taught in the normal way.

In the experimental group, the petroleum vocabulary teaching process was conducted from the prospective of memetics, which is shown in the following aspects:

Firstly, petroleum vocabulary memes were taught in the form of individual words (free morphemes). Generally, these free morphemes contributed to the compounds and blends in petroleum vocabulary. Since class time was very limited, the teacher only carefully chose about 10 words to explain explicitly from the words' associations, semantic maps, sense relations, etc., and the rest of words were left for students to learn by themselves or within their groups. The words chosen for explaining explicitly in class were usually very critical to the topics of the passages, or very useful and essential to summarize certain vocabulary learning strategy. After understanding and remembering one free morpheme clearly, it was easy to remember the related compounds, blends and phrases for students. By this way, students recited 5, or10, or even more words based on one-word meme at the same time. In this process, word memes experiencing many times of repetition grew into strong memes unconsciously.

Secondly, petroleum vocabulary memes were taught in the form of lexical chunks. During teaching, the teacher commonly listed several kinds of lexical chunks and gave several examples in each lexical chunk at the beginning. Then, the teacher gave the students a task to supply some other words to existed lexical chunk and find out new lexical chunks and the words belonged to each new type while reading the passages in this chapter. This task was also finished in group. So they could exchange their ideas with other members in their groups or even other classmates about the words and new lexical chunks they found to check whether they were right or not. Summarized and studied in group instead of individually, students had more chances and much interest to replicate and transmit these lexical chunks.

Thirdly, petroleum vocabulary memes were taught in the mean of bound morphemes, namely, in the form of roots, affixes, word-forming parts. During teaching, considerable emphasis was given to this part. The concrete teaching procedure was as follows: At first, students were asked to revise such terms as (free/bound) morpheme, root, stem, affix (prefix/suffix), inflectional morpheme, derivational morpheme that they have learned during the first two years of university. Then, the teacher taught students the most common and most transparent affixes and roots in petroleum English with examples systematically and explicitly. At last, students were given a task to extent the affixes and roots with petroleum vocabulary after class in groups. Also they could exchange their ideas among groups. Just as we can see, while students study, summarize and recite the affixes and roots, these bound morphemes as memes go through their lifecycles.

Finally, petroleum vocabulary memes were taught by the rules of word-formation. Memetic phenotype refers to the memes with the identical set pattern, but different contents. Obviously, vocabulary memes in the form of rules of word-formation belong to this type. During teaching, three major word-formation ways --- compounding, blending, derivation and conversion were introduced systematically and explicitly to students, because they are the three commonest way to form words in petroleum vocabulary. For example, many petroleum words expressing the drilling equipments are compounds, such as dogleg(angle of pipe that resembles the hind leg of a dog), horsehead(machine used to pump oil out, whose Chinese translate is very vivid), horsestone (a type of stone with many layers in which some mineral substance is contained ), etc. If the students know the meanings of the two parts of compounds, it's easier for them to remember the words by associate the words with the real machine. For another example, in petroleum vocabulary, many words get the new meanings different from their implications in daily life by conversion, such as 
"bit" is even known by every person as a very common word in daily life, whereas it means "boring crown". By knowing this kind of vocabulary memes through their word-formation, the students can guess, analogize or associate the meaning of new words related to the memes. After every class, tasks were given to the students aiming to recite and employ the vocabulary memes they learned in this class. These tasks not only stimulated the students' interest in discovering the meaning of strange words or phrases, but also made the vocabulary learning strategies transparent from the teacher to the students, or among the students, and thus easy for the students to imitate and transmit.

\section{Data presentation and Results Analysis of Pre-test and Post-test}

The students taking part in the research were in the second semester of junior year. They have been learning the petroleum engineering English in the first semester and were taught by the same teacher. Just because the students both in control class and experimental class have same petroleum engineering English learning experience, the author chose the final petroleum engineering English examination of the first semester of their junior year as the pre-test. At the same time, the paper of the final exam is designed and supervised by the whole teaching staff of petroleum engineering English and also scored by the whole staff together. That is to say, the validity and reliability of the exam could be ensured.

Table 1-1 Scores of pre-test of CG

\begin{tabular}{|c|c|c|c|}
\hline Number & Score & Number & Score \\
\hline 1 & 83 & 16 & 80 \\
\hline 2 & 75 & 17 & 76 \\
\hline 3 & 70 & 18 & 64 \\
\hline 4 & 68 & 19 & 68 \\
\hline 5 & 62 & 20 & 70 \\
\hline 6 & 73 & 21 & 69 \\
\hline 7 & 78 & 22 & 62 \\
\hline 8 & 82 & 23 & 63 \\
\hline 9 & 88 & 24 & 48 \\
\hline 10 & 63 & 25 & 67 \\
\hline 11 & 54 & 26 & 71 \\
\hline 12 & 74 & 27 & 85 \\
\hline 13 & 79 & 28 & 74 \\
\hline 14 & 74 & 29 & 64 \\
\hline 15 & 73 & 30 & 65 \\
\hline \multicolumn{4}{|c|}{ Table 1-2 Scores of pre-test of EG } \\
\hline Number & Score & Number & Score \\
\hline 1 & 73 & 16 & 78 \\
\hline 2 & 72 & 17 & 81 \\
\hline 3 & 84 & 18 & 61 \\
\hline 4 & 62 & 19 & 69 \\
\hline 5 & 73 & 20 & 72 \\
\hline 6 & 68 & 21 & 67 \\
\hline 7 & 75 & 22 & 64 \\
\hline 8 & 50 & 23 & 49 \\
\hline 9 & 62 & 24 & 72 \\
\hline 10 & 88 & 25 & 63 \\
\hline 11 & 82 & 26 & 68 \\
\hline 12 & 71 & 27 & 77 \\
\hline 13 & 76 & 28 & 85 \\
\hline 14 & 64 & 29 & 52 \\
\hline 15 & 73 & 30 & 71 \\
\hline
\end{tabular}


Based on the scores in Table1-1 and Table 1-2, the results of the pre-test are processed and list in Table 1-3.

Table 1-3 Independent Samples T-Test of the Results of Pre-test

Table 1-3 (a) Descriptive Statistics of the Pre-test

\begin{tabular}{l|l|l|l|l}
\hline class & N & Mean & Std. Deviation & Std. Error Mean \\
\hline CG & 30 & 70.7333 & 8.90538 & 1.62589 \\
\hline EG & 30 & 70.0667 & 9.71644 & 1.77397 \\
\hline
\end{tabular}

Table1-3(b) Independent Samples Test

\begin{tabular}{|c|c|c|c|c|c|c|c|c|c|}
\hline & \multicolumn{2}{|c|}{$\begin{array}{l}\text { Levene’s Test } \\
\text { for Equality } \\
\text { of Variances }\end{array}$} & \multicolumn{7}{|c|}{ t-test for Equality of Means } \\
\hline & \multirow[b]{2}{*}{$\mathrm{F}$} & \multirow[b]{2}{*}{ Sig. } & \multirow[b]{2}{*}{$\mathrm{t}$} & \multirow[b]{2}{*}{ df } & \multirow{2}{*}{$\begin{array}{c}\text { Sig. } \\
\text { (2-tailed) }\end{array}$} & \multirow{2}{*}{$\begin{array}{c}\text { Mean } \\
\text { Difference }\end{array}$} & \multirow{2}{*}{$\begin{array}{l}\text { Std. Error } \\
\text { Difference }\end{array}$} & \multicolumn{2}{|c|}{$\begin{array}{c}\text { 95\% Confidence Interval } \\
\text { of the Difference }\end{array}$} \\
\hline & & & & & & & & Lower & Upper \\
\hline $\begin{array}{l}\text { Equal } \\
\text { variances } \\
\text { assumed }\end{array}$ & .124 & .726 & .277 & 58 & .783 & .66667 & 2.40635 & -4.15016 & 5.48349 \\
\hline $\begin{array}{l}\text { Equal } \\
\text { variances } \\
\text { not assumed }\end{array}$ & & & .277 & 57.565 & .783 & .66667 & 2.40635 & -4.15093 & 5.48427 \\
\hline
\end{tabular}

From Table 1-3 (a), we can see that the control class and the experimental class get a mean score of 70.73 and 70.07 respectively. Compared with their performance in their freshmen and sophomore, the scores are not so satisfactory. That is because vocabulary, sentence pattern and passage arrangement of the petroleum engineering English are quite different from those of common English, and the students contacted with the petroleum engineering English for the first time. So in the new semester, the researcher and the teacher must try their best to guide students to be genuinely interested in the petroleum engineering English and make them motivated in their petroleum engineering English learning.

From Table 1-3 (b), since $F=0.124$ and Sig. value $P(0.726)>$ a $(0.05)$, equal variances are assumed. Therefore, we get the result of the $t$-test for equality of means: $t=0.227, v=58$, Sig. value $P$ $(0.783)>a(0.05)$. Hence, we can reach the conclusion that there is no significant difference in their petroleum engineering English proficiency between the experimental group and the control group before the research, and the justice and objectivity of this experiment can be made sure.

The post-test was performed at the end of the semester. For the complete same reason as that of the pre-test, the researcher also chose the final petroleum engineering English examination of this semester as the post-test in this research. The scores of the post-test are processed and shown in Table 1-4 and Table 1-5. 
Table 1-4 Scores of post-test of CG

\begin{tabular}{c|c|c|c}
\hline Number & Score & Number & Score \\
\hline 1 & 78 & 16 & 76 \\
\hline 2 & 66 & 17 & 80 \\
\hline 3 & 71 & 18 & 60 \\
\hline 4 & 63 & 19 & 67 \\
\hline 5 & 65 & 20 & 63 \\
\hline 6 & 76 & 21 & 66 \\
\hline 7 & 76 & 22 & 63 \\
\hline 8 & 78 & 23 & 57 \\
\hline 9 & 84 & 24 & 60 \\
\hline 10 & 60 & 25 & 72 \\
\hline 11 & 48 & 26 & 86 \\
\hline 12 & 74 & 27 & 68 \\
\hline 13 & 78 & 28 & 56 \\
\hline 14 & 70 & 29 & 60 \\
\hline 15 & 68 & 30 & \\
\hline
\end{tabular}

Table 1-5 Scores of post-test of EG

\begin{tabular}{c|c|c|c}
\hline Number & Score & Number & Score \\
\hline 1 & 81 & 16 & 83 \\
\hline 2 & 78 & 17 & 88 \\
\hline 3 & 86 & 19 & 70 \\
\hline 4 & 76 & 20 & 66 \\
\hline 5 & 80 & 21 & 80 \\
\hline 6 & 67 & 22 & 72 \\
\hline 7 & 83 & 23 & 63 \\
\hline 8 & 58 & 24 & 58 \\
\hline 9 & 70 & 25 & 65 \\
\hline 10 & 88 & 26 & 67 \\
\hline 11 & 90 & 27 & 76 \\
\hline 12 & 71 & 28 & 87 \\
\hline 13 & 82 & 29 & 78 \\
\hline 14 & 72 & 30 & \\
\hline 15 & 71 & & 68 \\
\hline
\end{tabular}

Based on the scores in Table1-4 and Table 1-5, the results of the post-test are processed and list in Table 1-6.

Table 1-6 (a) Descriptive Statistics of the post-test

\begin{tabular}{c|c|c|c|c}
\hline class & $\mathrm{N}$ & Mean & Std. Deviation & Std. Error Mean \\
\hline EG & 30 & 74.9667 & 8.86482 & 1.61849 \\
\hline CG & 30 & 67.8667 & 9.64806 & 1.76149 \\
\hline
\end{tabular}


Table1-6 (b) Independent Samples Test

\begin{tabular}{|c|c|c|c|c|c|c|c|c|c|}
\hline & \multicolumn{2}{|c|}{$\begin{array}{l}\text { Levene’s Test } \\
\text { for Equality } \\
\text { of Variances }\end{array}$} & \multicolumn{7}{|c|}{ t-test for Equality of Means } \\
\hline & \multirow[b]{2}{*}{$\mathrm{F}$} & \multirow[b]{2}{*}{ Sig. } & \multirow[b]{2}{*}{$\mathrm{t}$} & \multirow[b]{2}{*}{$\mathrm{df}$} & \multirow{2}{*}{$\begin{array}{c}\text { Sig. } \\
\text { (2-tailed) }\end{array}$} & \multirow{2}{*}{$\begin{array}{c}\text { Mean } \\
\text { Difference }\end{array}$} & \multirow{2}{*}{$\begin{array}{l}\text { Std. Error } \\
\text { Difference }\end{array}$} & \multicolumn{2}{|c|}{$\begin{array}{c}95 \% \text { Confidence Interval } \\
\text { of the Difference }\end{array}$} \\
\hline & & & & & & & & Lower & Upper \\
\hline $\begin{array}{l}\text { Equal } \\
\text { variances } \\
\text { assumed }\end{array}$ & .077 & .782 & 2.968 & 58 & .004 & 7.10000 & 2.39214 & 2.31161 & 11.88839 \\
\hline $\begin{array}{l}\text { Equal } \\
\text { variances } \\
\text { not assumed }\end{array}$ & & & 2.968 & 57.589 & .004 & 7.10000 & 2.39214 & 2.31088 & 11.88912 \\
\hline
\end{tabular}

From Table 1-5 (a), we get the mean score for the experimental class $(\mathrm{M}=74.97)$ and the mean score for control class ( $M=67.87)$. Judging from these two figures, there is a difference of 7 points between these two groups.

From Table 1-6 (b), since F=0.077 and Sig. value $\mathrm{P}(0.782)>$ a $(0.05)$, so equal variances are assumed. Accordingly, we get the Sig. value P (0.004) < a (0.05). That is to say, the difference between the experimental group and the control group in the post-test is significant or the memetics-oriented petroleum engineering English vocabulary teaching is relatively more effective.

\section{Conclusion}

Based on the analysis of data got in the research, we can find that vocabulary memes definitely can go through the intact growing process in petroleum engineering vocabulary teaching. So this new course design can cause a positive influence in the students' vocabulary learning to some degree because it can not only reduce their difficulty in petroleum engineering vocabulary learning, but also can promote their awareness in petroleum engineering English vocabulary learning strategies. That is to say, the memetics-oriented petroleum engineering English vocabulary teaching can improve students' ability of grasping petroleum engineering vocabulary. So the participants in the experimental group significantly outperformed their counterparts in the control group in the final English exam, namely, the post-test. Therefore, we can conclude, to some extent, the memetics-oriented petroleum engineering vocabulary teaching is more effective than the traditional way of vocabulary teaching which is based on textbook.

(Project Number: GJB1316012)

\section{References}

[1] Blackmore Susan. The Meme Machine [M]. Oxford: Oxford University Press, 1999: 38, 99, 58, 61, 107, 147.

[2] Distin K. The Selfish Meme - A Critical Reassessment [M]. Cambridge: Cambridge University Press, 2005.

[3] Ebbers, S.M. and C.A. Denton. A Root Awakening: Vocabulary Instruction for Older Students with Reading Difficulties [J]. Learning Disabilities Research \& Practice, 2008, (2) 90-102.

[4] Heylighen, F. Selection Criteria for the Evolution of Knowledge[C]. Proc 13th Int. Congress on Cybernetics, 1993, 524-528.

[5] Wilkins, J.S. Review The Selfish Meme [J]. Metascience, 2008, (17):269-271. 